\section{Irregular water supply, household usage and dengue: a bio-social study in the Brazilian Northeast}

\author{
Abastecimento irregular de água, seu uso \\ domiciliar e dengue: uma pesquisa biossocial no \\ Nordeste do Brasil
}

\author{
1 Departamento de Saúde \\ Pública, Universidade \\ Estadual do Ceará, Fortaleza, \\ Brasil. \\ 2 Escola de Saúde Pública do \\ Ceará, Fortaleza, Brasil. \\ 3 Special Programme for \\ Research and Training in \\ Tropical Diseases, World \\ Health Organization, Geneva, \\ Switzerland. \\ Correspondence \\ A. Caprara \\ Departamento de Saúde \\ Pública, Universidade \\ Estadual do Ceará. \\ Av. Paranjana 1700 \\ Fortaleza, $C E$ \\ 60740-000, Brasil. \\ caprara@uece.br
}

\begin{abstract}
Despite increased vector control efforts, dengue fever remains endemic in Fortaleza, Northeast Brazil, where sporadic epidemic outbreaks have occurred since 1986. Multiple factors affect vector ecology such as social policy, migration, urbanization, city water supply, garbage disposal and housing conditions, as well as community level understanding of the disease and related practices. This descriptive study used a multi-disciplinary approach that bridged anthropology and entomology. A multiple case study design was adopted to include research in six study areas, defined as blocks. The water supply is irregular in households from both under-privileged and privileged areas, however, clear differences exist. In the more privileged blocks, several homes are not connected to the public water system, but have a well and pump system and therefore irregularity of supply does not affect them. In households from under-privileged blocks, where the water supply is irregular, the frequent use of water containers such as water tanks, cisterns, barrels and pots, creates environmental conditions with a greater number of breeding areas. In under-privileged homes, there are more possible breeding areas and environmental conditions that may improve the chances of Aedes aegypti survival.
\end{abstract}

Dengue; Water Supply; Anthropology; Entomology

\author{
Andrea Caprara ${ }^{1}$ \\ José Wellington de Oliveira Lima \\ Alice Correia Pequeno Marinho 2 \\ Paola Gondim Calvasina 1 \\ Lucyla Paes Landim 1 \\ Johannes Sommerfeld 3
}

\section{Introduction}

Fortaleza, the capital city of Ceará State in Northeastern Brazil, is a peculiar urban context for dengue fever transmission. It has 2.2 million inhabitants and is one of the largest Brazilian metropolises, ranking fourth among the most populated cities in the country. The city is also ranked as one of the urban areas with high-income concentration, and huge differences exist between its poorest and richest residents 1 . Fortaleza is located in a hot, semi-arid region with an average annual rainfall of $1,200 \mathrm{~mm}$, compared with $400 \mathrm{~mm}$ in the interior of the state. Dengue fever has been endemic since 1986, with important outbreaks in 1987 (378/100,000), $1990(232 / 100,000), 1994$ (732/100,000), and $2001(456 / 100,000)$. In 2006, 172 hemorrhagic dengue fever cases were notified, along with 15 deaths 2 . After the 1994 epidemics, a survey revealed a seroprevalence of $45 \% 3$ in urban residents. In another Brazilian city, Salvador in Bahia State, the seroconversion found to be $70.6 \%$ in $2001{ }^{4}$. These data support the assumption that there is a high proportion of infected individuals in large cities in the Northeast of Brazil, with an accompanying elevated risk of epidemic dengue hemorrhagic fever.

There is a general lack of knowledge about the dynamics of community practices, state-based disease control, vector ecology and the wider political economic context 5,6,7. Such knowledge is needed to develop more effective dengue con- 
trol strategies. The framework shown in Figure 1 illustrates the complexity of the social, political and ecological determinants affecting dengue fever incidence in Fortaleza. It is not intended to be exhaustive; rather, it highlights factors that are hypothesized to play a role in dengue persistence in the face of intensified control measures. Three main domains make up the first organizational level: eco-biological, political-economic and social. The eco-biological domain encompasses elements such as vector ecology and biology, climate (temperature, rainfall); the politicaleconomic sphere includes, among other factors, social policy, migration, urbanization, city water supply, and garbage disposal; and the social level includes housing, basic sanitation, water supply and understandings and practices among the population ${ }^{8}$. A bio-social approach was adopted to identify both the biological and socio-behavioural factors 9,10,11,12,13 that have contributed towards the re-emergence of dengue fever including: poor housing and basic sanitation, lack of adequate water supply, the use of unprotected reservoirs for potable water, and no public garbage collection ${ }^{14}$. The study addresses the complexity of dengue fever emergence, in order to identify appropriate control strategies based on meaningful community involvement 15 .

From the bio-ecological perspective, the presence of the vector mosquito Aedes aegypti, and the quantity of breeding sites are the most important factors of Dengue occurrence 15. Domestic water storage containers are breeding sites for Ae. aegypti 16. In 2001, there were 278,000 potable water containers in Fortaleza. Many of them are still not protected from mosquito access. Studies focusing on prevention suggest considering housing conditions, social cohesion and risk perception, as well as community interpretations and practices affecting vector ecology 15 . Housing conditions are linked with water supply and storage, garbage disposal and consequently with the presence of breeding sites 17 .

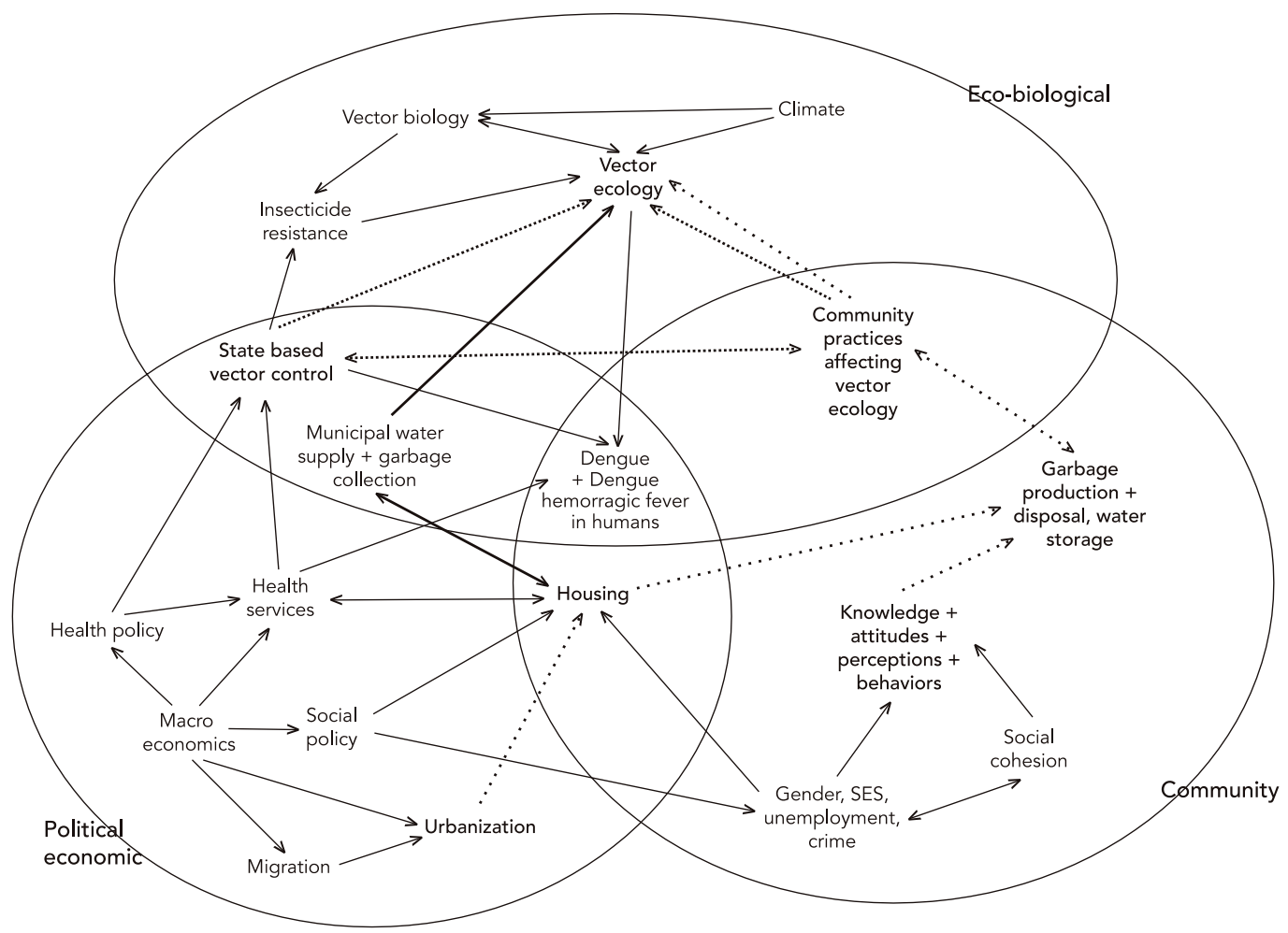


This study aims to investigate the relationship between the socio-economic characteristics and community practices that take place indoors (e.g. garbage disposal, water storage practices) affecting Ae. aegypti vector ecology in six selected blocks in the city of Fortaleza.

\section{Methods}

This descriptive study adopted an anthropological perspective, based mostly on qualitative methods, complemented by a household study of the vector's ecology, utilizing a quantitative approach. A case study was carried out in six blocks in the city of Fortaleza. Each block, according to the Brazilian Institute of Geography and Statistics 1, corresponds to approximately 40 houses. Administratively, the municipality of Fortaleza is divided into six "regions", each of them under the command of a Regional Executive Secretariats (SER). A block therefore selected in each one of the six SERs, with a view to understanding the ecological, biological, and social complexity and diversity of Fortaleza .

The selection process for the blocks was purposive 18 . The idea was not to choose a context that could subsequently be generalized to the whole, but to select a setting that showed salient features and behaviours which are relevant to the research questions ${ }^{19}$. In each of the six SERs, a block was selected according to the criteria of homogeneity of the houses: access to water, garbage collection, structural conditions, sewage system, health service assistance in case of disease, prevention, education and control activities. The research was to be carried out avoiding difficulties of access in the high income social stratum and slums or very poor areas with high violence levels that could put at risk the safety of the researchers.

\section{The context under study}

Blocks were selected as observation units to facilitate the ethnographic study. Per capita income in the middle-high class neighborhood was three times higher than in under-privileged socio-sanitary neighbourhoods.

Block A is located in Aldeota neighbourhood, a privileged location in the city of Fortaleza, it belongs to SER II. It has 36 houses of about eight rooms each, made of bricks with plastered walls. This block is provided with a public water supply, electricity, a sewage system and garbage collection (three times a week). The population disposes of its garbage in baskets used for this purpose. Theses services are regular without interruptions.

Block B is located in Alvaro Weyne neighbourhood and belongs to SER I. The water supply is through pipes from the public system. However, some residents do not have water pipes; they have pumps to withdraw water from a well. This block has 72 houses. Most of the constructions are made of masonry with outside walls and a sidewalk; some have a second floor, while few have garages. Water is stored in water tanks in all houses in this block; most of them are located outside the house. In most of the houses there is a water filter. Tanks, drums and clay jars are found in a few and only one house had a cistern. The public urban cleaning service is carried out through garbage collection three times a week.

Block C is located in Quintino Cunha neighbourhood and belongs to SER III, in the outskirts of Fortaleza. It contains 40 houses, some of which have façades, meaning that the precarious conditions can only be seen from inside the house: a high number of people living in cramped rooms, and unplastered walls, with termites and cracks. Many of the houses are detached, do not have a lined roof, and have inadequate ventilation and light. The water is supplied through the public system, CAGECE (Ceará Water and Sewer Company). Some residents use water from their own tank, others from a public fountain that is located two kilometers away. The water that is supplied by CAGECE always comes at dawn, although the days vary and the amount is not enough to go up the pipes to the water tanks located on roofs. In most of the houses we found tiles, bricks, tyres, bottles, stones, tins. However, garbage is collected regularly three times a week.

Block D is located in Itaperi neighbourhood, SER IV. It includes 200 houses, most of them made of masonry. The walls are not plastered, causing infiltrations and therefore humidity. They have inadequate ventilation and light. They are detached houses which were built using the neighbour's walls. Garbage collection takes place three times a week; however, many residents throw their home garbage in a waste ground opposite the block. This block is supplied by the public water system with constant interruptions. There is no supplementary private water supply.

Block E is located in Manoel Sátiro neighbourhood, SER V, and contains 47 houses, most of which have precarious light and ventilation, making them hotter and short of natural light. Water is supplied by CAGECE, however, not all families can afford this system. Although there is regular garbage collection three times a week 
some residents throw their garbage in waste grounds around the block.

Block F, located in Dias Macedo neighbourhood, SER VI, is composed of 39 houses. They are made of masonry, with outside walls and sidewalks, some of which have a second floor and garage. In this block there are detached houses and small rooms to let. The water is supplied from three sources: the main one is through the public piped network; another is in bulk from horsedrawn carts; and the third through motorised tanks. Garbage is collected three times a week. Despite this service, a lot of garbage can be found along sidewalks, as well as water that has been discarded from houses.

\section{Data collection}

An ethnographic and entomological study was carried out in each one of the six selected blocks between February and September 2005. Some preliminary workshops with community leaders helped to present the research objectives, inform them about the goals and methods and develop a process of consultation and dialogue to seek informed consent. The proposal has been discussed with the community and stakeholders before beginning the work in each one of the six selected study units. This process helped with the entrance and acceptance of social researchers in the field.

Ethnographic research was done based on participant observation and unstructured and open interviews, observing and participating in community practices related to vector ecology such as garbage disposal, water storage and daily activities. 42 in-depth interviews were carried out (11 in Block A, 2 in Block B, 7 in Block C, 8 in Block D, 7 in Block E, 7 in Block F) with community leaders, housewives, teenagers and some agents from each block. Leading questions were used in order to understand risk perceptions, illness interpretations and preventive practices adopted by the communities.

From the beginning, the entomological assessment process and the observation of household risk factors for Aedes infestation were integrated with the ethnographic data collection. The social researcher along with the endemic disease control agent visited each block twice a week for eight months. The in-depth observations helped to paint a picture of people's living conditions and the vector's environment, housing conditions, gender relationships and water supply. Among the overall material collected through participant observation, 31 field notes were transcribed and analysed (5 in Block A, 3 in Block B, 10 in Block C, 3 in Block D, 7 in Block E, 3 in Block F).
During the agents' routine visit to treat household water containers with larvicide (every two months), all household water containers were inspected, and larvae were collected and classified in the FNS (National Health Foundation) laboratory. The agents were also asked to observe the studied houses in order to collect data about the Aedes breeding and survival conditions. Such observations provided supporting information in the preparation of a questionnaire used to quantify data collection in the 204 houses, distributed in six blocks ( 36 houses in Block A, 15 houses in Block B, 38 houses in Block C, 40 houses in Block D, 36 houses in block E, 39 houses in block F). Using this instrument, the architecture of the houses, water supply and distribution, and the management of refuse were analysed. These instruments were conducted by the six endemic disease control agents during the research period.

Household characteristics were surveyed utilising a quantitative questionnaire in order to describe the scenario where the qualitative assessment was developed, and to evaluate which household characteristics would contribute to the abundance of Aedes.

\section{Data analysis and triangulation of qualitative and quantitative data}

Data from different sources were analysed through a methodological triangulation, using multiple methods to study a single problem (including interviews, observations, questionnaires and documents) 18 . This approach was mostly based on qualitative and quantitative observation (ethnographic and entomological).

The ethnographic data obtained from the blocks were put together according to their socio-economic-sanitary similarities. Two blocks with more privileged socio-sanitary conditions (referral name Block A, B) and four blocks of underprivileged socio-sanitary conditions (referral names Blocks, C, D, E, F).

Ethnographic field notes and other narratives were recorded, transcribed and entered into a qualitative database using the N.VIVO software package (QRS International Pty, Doncaster, Australia). Data were analysed through a content analysis approach based on grounded theory 20 . They were coded according to the main categories: living in good socio-sanitary conditions, water abundance, living in under privileged socio-sanitary conditions, water scarcity.

Computers helped to organize field notes, particularly the daily activities of women such as relationships with family and neighbours, water storage, and garbage disposal. All participant 
names were changed to preserve their identities. Relative frequencies of the presence of several risk factors were calculated (characteristics of households, characteristics of water supply system in households, characteristics of water distribution in households) for proliferation of $A e$. aegypti, according to blocks.

An ethical clearance document was signed by the Ethics Committee of Ceará State University as per the Project Proposal.

\section{Results and discussion}

The results of this study point to a complex interaction between socio-environmental inequalities and dengue control. In Fortaleza, the ethnographic data regarding the blocks involved in this study, as well as the interviews, portray the socio-economic-environmental and cultural complexity of a large metropolis in a developing country that has been fighting a serious public health problem such as dengue fever.

Living in privileged socio-sanitary conditions

In blocks A and B, where part of the high socio-economic strata of the population resides, people have access to an adequate network of public and private services. Block A, for example, is a neighbourhood with many high-rise apartment buildings: $67 \%$ of the people live in apartments 21 and others live in spacious houses. Residents in the block in this study live in houses with good light and gardens, some with swimming pools and garages. However, a small number of houses (six) have been transformed into commercial buildings. All the houses have high security walls with electric fences, barbed wires and nails. Most of the inhabitants are over 60 years old and retired, indicating the growth of the aging population in developing countries. The professions represented on the block include doctors, dentists, university professors, hairdressers, marketing professionals, and public sector workers. Most have maids to cook and clean the house, wash and iron clothes, in addition to some au-pairs (although there are few families with children that live here), gardeners and other intermittent service providers.

The structures of these neighbourhoods portray the social inequalities of a great metropolis in a developing country like Fortaleza: on the one hand, there is great proximity to the most expensive shops (there are four shopping centres in the surrounding area), high quality goods and services (restaurants, supermarkets, banking networks, private clinics and hospitals, pri- vate schools and universities, gyms and beauty care centres); while on the other hand, about 100 meters from Block A, another block known as the "quadra" (not part of the study), which means "block" or "sports court", shelters in its perimeter a population of 1,936 people, and 20 mini-blocks, with 757 houses cramped next to one another, with no yards or suitable places for drying clothes, unplastered, unpainted walls and floors made from burnt cement. This is a very relevant fact for it reveals how complex the problem is, even in more privileged areas where there are "clusters" of poverty that can aggravate the problem of dengue fever.

\section{Water abundance and dengue}

Public services provide almost all the houses with water supply, energy, sanitation, and regular garbage collection three times a week, which are regular and rarely interrupted. In some houses, old tanks for storing water from the rain can be found, reminiscent of a time when potable water supply did not exist in that region, or services were precarious. As shown in Table 1, a significantly high percentage of middle class homes has a private water supply system (well and/or water tank). The current method of storing water is the use of sealed or netted roof tanks, located in the ceiling under the roof of the house, that receive an uninterrupted potable water supply from CAGECE (the company responsible for the public water supply in Fortaleza). Elements of Brazilian culture take pride in the idea that the country has an abundant supply of fresh water from large rivers and the Amazon forest, yet this drinking water is used for everything but drinking. Instead it is used for household chores, such as house cleaning, cooking, washing clothes and personal hygiene, which may be due its excessively salty flavour, or because people do not trust the quality of the water. The mineral water consumption in plastic reusable bottles is part of the local culture; therefore there is an extensive and efficient sale and distribution network, with delivery services. There are also appliances that hold and chill large water dispensers.

An excerpt from the field notes of one Block A researcher narrates a scene relating to the use of water by residents: "I went to the block on Saturday morning. I met Mrs. J, who is Mrs. D.'s maid and was giving the house a "spring" cleaning, washing the porch and the side walk with water spurts coming out of the hose. The water went down the street and was soon absorbed. The hot sun also made the water evaporate quickly. Four houses along, Mr. F. watched a young man wash- 
Characteristics of water supply system in households $(N=204)$ included in the study.

\begin{tabular}{|c|c|c|c|c|c|c|}
\hline \multirow[t]{3}{*}{ Characteristics of water supply system } & \multirow{2}{*}{\multicolumn{2}{|c|}{ Total }} & \multicolumn{4}{|c|}{ Households on typical blocks of } \\
\hline & & & \multicolumn{2}{|c|}{ Middle class $(n=51)$} & \multicolumn{2}{|c|}{ Under-privileged class $(n=153)$} \\
\hline & $\mathrm{n}$ & $\%$ & $\mathrm{n}$ & $\%$ & $\mathrm{n}$ & $\%$ \\
\hline \multicolumn{7}{|l|}{ Presence of public water supply system } \\
\hline No & 25 & 12.2 & 12 & 23.5 & 13 & 8.5 \\
\hline Yes & 179 & 87.8 & 39 & 76.5 & 140 & 91.5 \\
\hline \multicolumn{7}{|l|}{ Water reaches home (days/week) } \\
\hline 2 to 5 & 30 & 16.8 & 0 & 0.0 & 30 & 21.4 \\
\hline 6 to 7 & 149 & 83.2 & 39 & 100.0 & 110 & 78.6 \\
\hline \multicolumn{7}{|l|}{ Water reaches home (hours/day) } \\
\hline 3 to 12 & 60 & 33.5 & 23 & 59.0 & 37 & 26.4 \\
\hline 13 to 24 & 119 & 66.5 & 16 & 41.0 & 103 & 73.6 \\
\hline \multicolumn{7}{|l|}{ Upper water tank: } \\
\hline No & 62 & 30.4 & 11 & 21.6 & 63 & 41.4 \\
\hline Yes & 142 & 69.6 & 40 & 78.4 & 90 & 58.6 \\
\hline \multicolumn{7}{|l|}{ Water goes up to water tank } \\
\hline No & 17 & 12.0 & 3 & 8.0 & 14 & 13.6 \\
\hline Yes & 125 & 88.0 & 36 & 92.0 & 89 & 86.4 \\
\hline \multicolumn{7}{|l|}{ Water supply by well } \\
\hline No & 167 & 82.7 & 36 & 70.6 & 131 & 86.8 \\
\hline Yes & 35 & 17.3 & 15 & 29.4 & 20 & 13.2 \\
\hline
\end{tabular}

ing his car that was parked in the street, also with a hose with abundant water" (Excerpt from field notes).

In general, residents are careful with natural breeding sites, they avoid having vases with plants or flowers at home, or water fountains in the garden, due to the fear of insect reproduction. However, to perform dengue control at the household level seems to demand detailed everyday care that goes beyond the willingness of most people. The sanitary agents end up doing this job during their bi-monthly visits that are insufficient in periods of rain.

After rainfall, water usually drains quickly in the streets; however, there are always streets in the surrounding areas that form water puddles in the rainy season. In such cases, the "fumacê" (a car that sprays ultra low volume insecticide in the streets) is frequently used. This control practice is so common in Block A, located in Aldeota neighbourhood, that it is part of the local culture to complain that, "it passes through Aldeota only", meaning this solution is only available to the rich. When the inhabitants need medical services, they use their private health plans to go to the private clinics and hospitals, many of them located within the neighbourhood, where there high quality services are available. There is a basic health unit nearby, which is in charge of primary health care, prevention and promotion, and serves as the first point of call within the health system, which is universal in Brazil and organized in a hierarchic fashion, from low to high technological complexity. However, the Brazilian middle class only uses the public health service in cases when their private insurance does not cover the disease or in emergency situations such as a car crash.

\section{Living in under-privileged socio-sanitary} neighbourhoods

Almost one quarter (22\%) of the more than two million inhabitants of Fortaleza earn the equivalent of the minimum wage (R\$300.00, which, as at March 2007 was equal to US\$ 145) in neighbourhoods belonging to the under-privileged social classes 1 . However, there is considerable heterogeneity in the living conditions from block to block. One aspect they all share is problems with water supply and refuse collection, which directly hamper dengue control practices.

The four lower-class neighbourhoods, where blocks under study are located, show similar indicators: around four inhabitants per dwelling; per capita monthly income between R\$ 240.00 
and $\mathrm{R} \$ 400.00$ with an average of $\mathrm{R} \$ 300.00$; illiteracy rates above the national average, reaching $18 \%$ in one of the neighbourhoods studied; the public water distribution network (CAGECE) covers more than $80 \%$ of dwellings in the neighbourhoods, except in one where only $58.95 \%$ are covered (Block C). The supply of water is irregular in all neighbourhoods. Refuse collection is a serious problem in all neighbourhoods, varying from $7.23 \%$ to $55.5 \%$.

In the under-privileged socio sanitary blocks, there is a mix of lower-middle class standard houses and poorer houses. Most dwellings are brick, yards, walls and sidewalks; very few have garages attached to the house and few inhabitants have cars. Although the city of Fortaleza is sunny all year round and is on the coast, many of the houses are dark, with limited ventilation, which makes them hot and practically devoid of natural light.

The families in these blocks consist of three or four people and there are not many children, an average of two per home, reflecting the decline in the Brazilian birth rate in recent years 1 . Most houses are rented and some inhabitants come from municipalities in the countryside and migrated to the capital in search of better living conditions (Fortaleza has received immigrants escaping inland droughts since the 19th Century). These immigrants maintain the habit of sitting on the pavement and leaning out of windows facing the street, especially at the end of the day, when the sun is weaker and the temperature more pleasant.

In Fortaleza, the unemployment rate is high, $13.82 \%$ in December 2005, with an informal occupation rate of $55.44 \% 22$. In most of the families visited there was someone unemployed. Furthermore, the problem of alcoholism seems to be aggravated by this situation.

\section{Water scarcity and dengue}

Although the public system supplies water to over $80 \%$ of the dwellings in the under-privileged blocks, the people there face daily water supply problems. This situation is aggravated by the fact that some inhabitants have no plumbing in their homes, whether due to the absence of public services in the dwelling or because not all families can afford it. One house in Block E had its water supply cut off due to lack of payment two years ago and, to this day, has been unable to afford reconnection.

Thus, the inhabitants buy water from other sources, such as buying in bulk from horse-drawn carts; from motorised tanks; or from people who walk around the streets with large cans of water.
This irregularity (or inexistence, in some cases) of water supply from the public sphere leads the population to store water in various containers such as water tanks, cisterns, barrels, drums, bowls, pots, water filters and others. The sealing of water tanks is a practice that has been implemented by the dengue fever eradication programme, but not all dwellings have tanks with lids or mesh, and facilitate reproduction of the vector. Another means of control adopted in Fortaleza and used in some dwellings, is the use of beta fish in tanks, but its efficiency is debatable, as shown in a recent study 23 .

The population uses water from the public system (CAGECE) for drinking, cooking and personal hygiene. However, in some houses, even those with running water, people use drums and pots for drinking or bathing. Some local inhabitants use filters for drinking water.

Larvae and people currently affected by the disease were found in all the under-privileged blocks studied. On Block D, for example, inhabitants were very well informed regarding how to prevent dengue fever and fight the mosquito that spreads it 24 . Nevertheless, even in some wellconstructed houses with adequate hygiene and no mosquito breeding grounds, the larvae of $A e$. aegypti were found. The problem of abandoned land also occurs in the other under-privileged neighbourhoods.

It is a poor population that cannot afford to have their own roof tank and in order to solve the water shortage problem, has acquired the habit of waking up daily at dawn to open taps and fill up buckets and drums. The problem is that when they solve their problem of a lack of water, they contribute to dengue reproduction in the neighbourhood. There was found to be carelessness in cleaning the containers: a positive dengue breeding source was found in a drum containing stored water in a house in Block D in the Itaperi neighbourhood, for example, despite the fact that it was connected to the public water supply. According to 18 year old João, who was met during the household visit, the water drum was stored for a week when there was no available public water supply.

"Our water comes straight from CAGECE; we don't have a roof tank. Then, on Friday they said there would be no water on Saturday, so we filled it [the drum] half way up. It came back on Saturday night, around 11 o'clock (...) I even looked at it yesterday and thought "I'll pour it down", but I forgot and it remained there" (José, resident in Block D, Itaperi).

This student in his last year at high school revealed knowledge and information about the dengue fever problem, that was, he claimed, ac- 
quired at school and through television, but neither he nor his relatives have taken the issue as their own, for they forget to take the necessary actions to prevent dengue in their households.

In Block $\mathrm{C}$ there people have organized themselves to obtain water in response to irregularities in the public supply system. The water supplied by CAGECE always comes at dawn, there are no fixed days, and there is so little of it that it cannot go up to the roof tanks of the houses, and instead the women in the area wake up at dawn daily to open the tap and fill their buckets, as described in this narrative from Maria Rosa, a resident of Block C in Quintino Cunha: "It's because the water gets to some houses, and doesn't to others. There are those difficulties, it comes at dawn. Sometimes the people oversleep, they don't wake up in time to get the water. My father helps me to get it [water]; he's a man in his eighties. He turns on the tap over there in the buckets so as we can get it. We put it in the buckets, in the cistern. I've got a neighbour who leaves home at four in the morning and before he goes out, he fills up the containers".

Despite visits from endemic diseases control agents and access to information on dengue prevention practices, prevention activities among the population are limited by the precarious water supply service. Oliveira \& Valla 25 write that it is all about possible choices within a field of possibilities, limited by the precariousness of services.

\section{Households and vector ecology}

When adult forms of Ae. aegypti remain inside homes, the most important factor for their survival is relative humidity 26 . The kind of home environment that best favours the process of colonization by adult forms of Ae. aegypti is not yet known. Even if the relative humidity indoors or outdoors was not measured, we could infer that the type of home construction may play host to high indoor humidity which facilitates the presence of adult forms. This may include un-plastered walls, un-lined floors, especially bathrooms, or other factors that increase the humidity indoors, aiding reproduction of the Aedes mosquito. In this study of under-privileged socio sanitary blocks, the following were observed (Table 2): (i) a significantly smaller percentage of homes with plastered walls; (ii) a significantly higher percentage of homes with cement floors; (iii) a significantly lower percentage of homes with less porous floors (ceramic); (iii) a significantly lower percentage of homes with tiled bathrooms. In other words, the type of home construction in under-privileged neighbourhoods seems to allow a higher relative humidity and thus a more appropriate environment for survival of $A e$. aegypti adults 26 .

During the rainy season, yards with trees and claylike soil may allow small puddles to form. These may increase humidity which may allow adult $A e$. aegypti to survive longer 26 . Similarly, the presence of trees may protect these breeding areas from sunlight, improving conditions for the multiplication of larvae. In addition, water troughs for domesticated animals, such as poultry, cats, dogs and caged birds may increase the number of potential breeding spots. The presence of pets may also be associated with dirtier surfaces (walls and floors) which may increase the relative humidity of the air inside the home, providing an ideal environment for adult forms of Aedes, by means of the mechanism proposed in the previous paragraph. In under-privileged blocks, the following characteristics were noted (Table 3): (i) a higher (but not significant) percentage of homes with yards with claylike soil; (ii) a significantly higher percentage of homes with birds, cats and poultry. In summary, these results suggest that in under-privileged homes, there are more possible breeding areas and environmental conditions that may improve Ae. aegypti survival rates.

In this study (Table 1), it was observed that: (i) a significantly large percentage of under-privileged homes is served by the public water supply, whilst a significantly high percentage of middle class homes has a private water supply system (well and/or water tank); (ii) the supply system to the under-privileged provides water with a significantly lower weekly frequency, but for a significantly longer daily duration. That is, the water supply to the under-privileged was less reliable with regard to the weekly frequency with which water reached the home, but was nevertheless more reliable with regard to the number of hours per day that water is supplied. The impact of the regularity of the water supply also depends on the volume of water storage available. When there are large containers in the home (water tanks, cisterns) that prevent access to female $A e$. aegypti, intermittent supply may not increase the abundance of Ae. aegypti.

It is presumed that appropriate distribution of water within the household, through showers, washbasins, kitchen sinks and sinks for washing clothes, reduces the need for containers to transport water and, consequently, minimizes potential breeding spots. In the area studied a significantly lower percentage of under-privileged homes were found with washbasins and sinks for washing clothes (Table 4). As a result, the need for containers to transport water in under-privileged homes is greater than in middle class homes. 
Characteristics of the households $(N=204)$ included in the study.

\begin{tabular}{|c|c|c|c|c|c|c|}
\hline \multirow[t]{3}{*}{ Characteristics } & \multicolumn{2}{|c|}{ Total } & \multicolumn{4}{|c|}{ Households on typical blocks of } \\
\hline & \multirow[b]{2}{*}{$\mathrm{n}$} & \multirow[b]{2}{*}{$\%$} & \multicolumn{2}{|c|}{ Middle class $(n=51)$} & \multicolumn{2}{|c|}{ Under-privileged class $(n=153)$} \\
\hline & & & $\mathrm{n}$ & $\%$ & $\mathrm{n}$ & $\%$ \\
\hline \multicolumn{7}{|l|}{ Brick walls } \\
\hline No & 1 & 0.5 & 0 & 0.0 & 1 & 0.6 \\
\hline Yes & 203 & 99.5 & 51 & 100.0 & 152 & 99.4 \\
\hline \multicolumn{7}{|c|}{ Clay and wood walls } \\
\hline No & 201 & 98.5 & 51 & 100.0 & 150 & 98.0 \\
\hline Yes & 3 & 1.5 & 0 & 0.0 & 3 & 2.0 \\
\hline \multicolumn{7}{|c|}{ All walls plastered } \\
\hline No & 43 & 21.1 & 4 & 7.8 & 39 & 25.5 \\
\hline Yes & 161 & 78.9 & 47 & 92.2 & 114 & 74.5 \\
\hline \multicolumn{7}{|c|}{ Compacted dirt floor } \\
\hline No & 200 & 98.0 & 50 & 98.0 & 150 & 98.0 \\
\hline Yes & 4 & 2.0 & 1 & 2.0 & 3 & 2.0 \\
\hline \multicolumn{7}{|c|}{ Unlined brick floor } \\
\hline No & 203 & 99.5 & 50 & 98.0 & 153 & 100.0 \\
\hline Yes & 1 & 0.5 & 1 & 2.0 & 0 & 0.0 \\
\hline \multicolumn{7}{|l|}{ Cement floor } \\
\hline No & 92 & 45.0 & 34 & 66.7 & 58 & 37.9 \\
\hline Yes & 112 & 55.0 & 17 & 33.3 & 95 & 62.1 \\
\hline \multicolumn{7}{|c|}{ Ceramic tiled floor } \\
\hline No & 88 & 43.1 & 9 & 17.6 & 79 & 51.6 \\
\hline Yes & 116 & 56.9 & 42 & 82.4 & 74 & 48.4 \\
\hline \multicolumn{7}{|l|}{ Tiled bathroom } \\
\hline No & 101 & 49.5 & 13 & 25.5 & 88 & 57.5 \\
\hline Yes & 103 & 50.5 & 38 & 74.5 & 65 & 42.5 \\
\hline
\end{tabular}

Finally, some considerations about the limits of the research: in the study area we assessed the Aedes infestation twice: during the rainy season (April to May) and during the dry season (AugustSeptember). There were only five infested households in the rainy period and four during the dry one (data not shown in tables). Unfortunately these figures did not allow us to assess infestation according to social class and Aedes preference for breeding sites. However, an unusual event was observed between the two surveys in Block C, where 17 households out of 40 (42\%) were found to be infested. Additionally, cases of dengue were not reported from the study area during the observation period.

\section{Conclusions}

There are clear differences between the least and most privileged blocks. In the privileged ones, several houses are not even connected to the public water system for they have their own well and pump system, therefore the irregularity does not affect them. On the other hand, the clearest difference in terms of supply, given that the rich do not suffer from supply irregularity, is the capacity of storage, leading the population from under-privileged areas to multiply the number of barrels, drums, bowls and pots at household level. In households in under-privileged neighbourhoods, the type of construction seems to allow a higher relative humidity and thus a more appropriate environment for adult forms of the Ae. aegypti mosquito. There are also more breeding areas and environmental conditions that may facilitate the survival of adult forms of Ae. aegypti. Since the piped water supply is irregular, this leads to more water storage in containers. Differences found in access to water between socio economic groups may be a determinant in dengue control. The presence of breeding sites in the privileged blocks are due to water used for pleasure such as foun- 
Table 3

Characteristics of the household yards $(N=204)$ included in the study.

\begin{tabular}{|c|c|c|c|c|c|c|}
\hline \multirow[t]{3}{*}{ Characteristics } & \multicolumn{2}{|c|}{ Total } & \multicolumn{4}{|c|}{ Households on typical blocks of } \\
\hline & \multirow[b]{2}{*}{$\mathrm{n}$} & \multirow[b]{2}{*}{$\%$} & \multicolumn{2}{|c|}{ Middle class $(n=51)$} & \multicolumn{2}{|c|}{ Under-privileged class $(n=153)$} \\
\hline & & & $\mathrm{n}$ & $\%$ & $\mathbf{n}$ & $\%$ \\
\hline \multicolumn{7}{|c|}{ Presence of a yard } \\
\hline No & 31 & 15.2 & 10 & 19.6 & 21 & 13.7 \\
\hline Yes & 173 & 84.8 & 41 & 80.4 & 132 & 86.3 \\
\hline \multicolumn{7}{|c|}{ Clay soil-type in the yard } \\
\hline No & 142 & 85.5 & 39 & 95.1 & 103 & 82.4 \\
\hline Yes & 24 & 14.5 & 2 & 4.9 & 22 & 17.6 \\
\hline \multicolumn{7}{|c|}{ Presence of trees casting shade } \\
\hline No & 114 & 65.9 & 28 & 68.3 & 86 & 65.2 \\
\hline Yes & 59 & 34.1 & 13 & 31.7 & 46 & 34.8 \\
\hline \multicolumn{7}{|l|}{ Presence of birds } \\
\hline No & 159 & 77.9 & 45 & 88.2 & 114 & 74.5 \\
\hline Yes & 45 & 22.1 & 6 & 11.8 & 39 & 25.5 \\
\hline \multicolumn{7}{|l|}{ Presence of cats } \\
\hline No & 175 & 85.8 & 48 & 94.1 & 127 & 83.0 \\
\hline Yes & 29 & 14.2 & 3 & 5.9 & 26 & 17.0 \\
\hline \multicolumn{7}{|l|}{ Presence of dogs } \\
\hline No & 143 & 70.0 & 38 & 74.5 & 105 & 68.7 \\
\hline Yes & 61 & 30.0 & 13 & 25.5 & 48 & 31.3 \\
\hline \multicolumn{7}{|c|}{ Presence of cats and dogs } \\
\hline No & 129 & 63.2 & 35 & 68.6 & 94 & 61.4 \\
\hline Yes & 75 & 36.8 & 16 & 31.4 & 59 & 38.6 \\
\hline
\end{tabular}

Table 4

Characteristics of water distribution in households $(N=204)$ included in the study.

\begin{tabular}{|c|c|c|c|c|c|c|}
\hline \multirow[t]{3}{*}{ Characteristics } & \multicolumn{2}{|c|}{ Total } & \multicolumn{4}{|c|}{ Households on typical blocks of } \\
\hline & \multirow[b]{2}{*}{$\mathrm{n}$} & \multirow[b]{2}{*}{$\%$} & \multicolumn{2}{|c|}{ Middle class $(n=51)$} & \multicolumn{2}{|c|}{ Under-privileged class $(n=153)$} \\
\hline & & & $\mathrm{n}$ & $\%$ & $\mathrm{n}$ & $\%$ \\
\hline \multicolumn{7}{|c|}{ Presence of bathroom } \\
\hline No & 5 & 2.4 & 2 & 3.9 & 3 & 2.0 \\
\hline Yes & 199 & 97.6 & 49 & 96.1 & 150 & 98.0 \\
\hline \multicolumn{7}{|c|}{ Presence of shower } \\
\hline No & 35 & 17.2 & 5 & 9.8 & 30 & 19.6 \\
\hline Yes & 169 & 82.8 & 46 & 90.2 & 123 & 80.4 \\
\hline \multicolumn{7}{|c|}{ Presence of wash basin } \\
\hline No & 81 & 39.7 & 10 & 19.6 & 71 & 46.4 \\
\hline Yes & 123 & 60.3 & 41 & 80.4 & 82 & 53.6 \\
\hline \multicolumn{7}{|c|}{ Presence of kitchen sink } \\
\hline No & 21 & 10.3 & 3 & 5.9 & 18 & 11.8 \\
\hline Yes & 183 & 89.7 & 48 & 94.1 & 135 & 88.2 \\
\hline \multicolumn{7}{|c|}{ Presence of sink for washing clothes } \\
\hline No & 50 & 24.5 & 6 & 11.8 & 44 & 28.8 \\
\hline Yes & 154 & 75.5 & 45 & 88.2 & 109 & 71.2 \\
\hline
\end{tabular}


tains, decorative flower pots, etc. Those in the under-privileged areas are the result of storing water in inadequate containers such as pots, tanks, drums, and wells as they do not have access to running water. Moreover results show that even in more affluent areas, there are "clus- ters" of poverty which can aggravate the problem of Dengue Fever in the area. Dengue fever is a complex disease that affects the rich and poor as a result of their differing household water practices, with varying consequences for public health approaches.

\section{Resumo}

Apesar do crescimento de esforços no controle, desde 1986, a dengue, em Fortaleza, Nordeste do Brasil, continua endêmica com esporádicos surtos epidêmicos. Diversos fatores influenciam a ecologia do vetor, como as políticas sociais, a migração, a urbanização, o abastecimento urbano de água, a coleta de resíduos sólidos, as condições das casas, assim como as interpretações e práticas da comunidade. Este estudo descritivo utiliza uma abordagem multidisciplinar conjugando a antropologia e a entomologia. Foi adotado um desenho de estudo de caso múltiplo em seis quarteirões da cidade. O abastecimento de água é irregular seja nas casas pobres, seja naquelas privilegiadas. Apesar disso, existem diferenças entre os quarteirões em áreas pobres e aqueles mais privilegiados. Nos quarteirões mais privilegiados, existem casas que não têm ligação com o sistema de abastecimento público mas têm sistemas com poço e bomba, por isso a irregularidade não os afeta. Nos domicílios mais pobres, onde o abastecimento de água é irregular, a utilização de reservatórios como caixas d'água, cisternas, tambores, potes, cria as condições ambientais para um maior número de criadouros potenciais que poderiam incrementar a sobrevivência do Aedes aegypti.

Dengue; Abastecimento de Água; Antropologia; Entomologia

\section{Contributors}

The authors participated in the research design, execution and analysis. They also participated in writing the paper and approving the final version.

\section{Acknowledgments}

We wish to thank our colleagues Ellen Rodrigues Lima, Luisilda Maria Dernier Martins Santana, Fátima Maria de Sousa Sales, and Fábio Angelo Lima Verde Araújo, who participated in the data collection process. We would like to thank the scholars involved in the transcription of the text: Amanda Nobre, Carol Arcanjo and Carlos Maximiliano. We are grateful to Mardênia Gomes Ferreira Vasconcelos for her impeccable support as well as Eddie William de Pinho Santana for secondary data collection. We also thank the six technicians of the National Health Foundation (FNS) who assisted and participated in the data collection process. We are particularly grateful to Dominique F. Charron who helped develop the eco-health framework and Roberto Bazzani, José Luis San Martín, and Ana Maria Boischio for the suggestions and improvements of the project proposal. The authors also thank Margaret Becker for her assistance in revising the text. The research was developed with the support of the United Nations Children's Fund/International Development Research Centre \& United Nations Development Programme/World Bank/World Health Organizations - The Special Programme for Research \& Training in Tropical Diseases (TDR), ID A40001, File number: T28-181-73. 


\section{References}

1. Instituto Brasileiro de Geografia e Estatística. Synthesis of social indicators present a portrait of Brazil in 2003. Social communication. http://www. ibge.gov.br (accessed on 24/Feb/2005).

2. Secretaria da Saúde do Estado do Ceará. Informe semanal dengue 2007. http://www.saude.ce.gov.br (accessed on 02/Mar/2007).

3. Vasconcelos PFC, Lima JWO, Rosa APAT, Timbó MJ, Rosa EST, Lima HR, et al. Epidemia de dengue em Fortaleza, Ceará: inquérito soro-epidemiológico aleatório. Rev Saúde Pública 1998; 32:447-54.

4. Teixeira MG, Barreto ML, Costa MCN, Ferreira LDA, Vasconcelos PFC, Cairncross S. Dynamics of dengue virus circulation: a silent epidemic in a complex urban area. Trop Med Int Health 2002; 7: 757-62.

5. Possas CA. Social ecosystem health: confronting the complexity and emergence of infectious diseases. Cad Saúde Pública 2001; 17:31-41.

6. Penna MLF. Um desafio para a saúde pública brasileira: o controle da dengue. Cad Saúde Pública 2003; 19:305-9.

7. Tauil PL. Urbanização e ecologia do dengue. Cad Saúde Pública 2001; 17 Suppl:S99-102.

8. World Health Organization. Dengue and dengue hemorrhagic fever fact sheet, 2005. http://www. who.int/mediacentre/factsheets/fs117/en/ (accessed on 20/Oct/2005).

9. Farmer P, Becerra M. Biosocial research and the TDR agenda. Geneva: World Health Organization; 2001. (TDR News, 66).

10. Waltner-Toews D. An ecosystem approach to health and its applications to tropical and emerging diseases. Cad Saúde Pública 2001; 17 Suppl: 7-36.

11. Lebel J. In focus: health - an ecosystem approach. Ottawa: International Development Research Centre; 2003.

12. Spiegel J, Bonet M, Garcia M, Ibarra AM, Tate RB, Yassi A. Building capacity in central Havana to sustainably manage environmental health risk in an urban ecosystem. EcoHealth 2004; 1 Suppl 12:120-30.

13. Berrang-Ford L, Waltner-Toews D, Charron D, Odiit M, McDermott J, Smith B. Sleeping sickness in Southeastern Uganda: a systems approach. EcoHealth 2005; 2:183-94.
14. Nichter M. Vaccinations in South Asia: false expectations and commanding metaphors. In: Coreil J, Mull JD, editors. Anthropology and primary health care. Boulder: Westwood Press; 1990. p. 196-221.

15. Lenzi, MF, Carmello-Coura L, Grault CE, Val MB. Estudo do dengue em área urbana favelizada no Rio de Janeiro: considerações iniciais. Cad Saúde Pública 2000; 16:851-6.

16. Barrera R, Delgado N, Jimenez M, Valero S. Ecoepidemiological factors associated with hyperendemic dengue haemorrhagic fever in Amracay City, Venezuela. Dengue Bulletin 2002; 26:86-95.

17. Forattini OP, Brito M. Reservatórios domiciliares de água e controle do Aedes aegypti. Rev Saúde Pública 2003; 37:676-7.

18. Patton MQ. How to use qualitative methods in evaluation. London: Sage Publications; 1987.

19. Pope C, Mays N. Qualitative research in health care. London: BMJ Books; 2000.

20. Morse JM, Richards L. Readme First. For a user's guide to qualitative methods. Thousand Oaks: Sage Publications; 2002.

21. Secretaria Municipal de Saúde de Fortaleza. Relatório de controle da dengue-SER II. Fortaleza: Secretaria Municipal de Saúde de Fortaleza; 2004

22. Sistema Nacional de Emprego. Ocupação e desemprego no Município de Fortaleza. Pesquisa mensal, dezembro 2005. Fortaleza: Sistema Nacional de Emprego; 2005.

23. Cavalcanti LPG, Lima JWO, Cunha JCL, Santana EWP. Avaliação do impacto na infestação por Aedes aegypti em tanques de cimento do município de Canindé, Ceará, Brasil, após a utilização do peixe Betta splendens como alternativa de controle biológico. Rev Soc Bras Med Trop 2004; 37:400-4.

24. Claro LBL, Tomassini HCB, Rosa MLG. Prevenção e controle do dengue: uma revisão de estudos sobre conhecimentos, crenças e práticas da população. Cad Saúde Pública 2004; 20:1447-57.

25. Oliveira RM, Valla VV. As condições e as experiências de vida de grupos populares no Rio de Janeiro: repensando a mobilização popular no controle do dengue. Cad Saúde Pública 2001; 17 Suppl:77-88.

26. Thu HM, Aye KM, Thein S. The effect of temperature and humidity on dengue virus propagation in Aedes aegypti mosquitos. Southeast Asian. J Trop Med Public Health 1998; 29:280-4.

Submitted on $06 /$ Nov/2007

Final version resubmitted on 02/Apr/2008 Approved on 15/May/2008 